\title{
Constitutional and mosaic large NF1 gene deletions in neurofibromatosis type 1
}

Sonja A Rasmussen, Steven D Colman, Vu T Ho, Corinne R Abernathy, Pamela H Arn, Lester Weiss, Charles Schwartz, Robert A Saul, Margaret R Wallace

Department of Pediatrics, Division of Genetics, Box 100296, University of Florida College of Medicine, Gainesville, FL 32610-0296, USA $S$ A Rasmussen $S$ D Colman V T Ho

C R Abernathy M R Wallace

Center for Mammalian Genetics, University of Florida College of Medicine, Gainesville, FL, USA

S A Rasmussen

$S$ D Colman

M R Wallace

Nemours Children's Clinic, Jacksonville, FL, USA

P H Arn

Medical Genetics and Birth Defects Center, Henry Ford Hospital, Detroit, MI, USA L Weiss

Greenwood Genetics Center, Greenwood, SC, USA

C Schwartz

R A Saul

Department of Biochemistry and

Molecular Biology, and Department of Pathology,

Immunology and Laboratory Medicine, University of Florida College of Medicine, Gainesville, FL, USA M R Wallace

Correspondence to: Dr Wallace.

Received 4 August 1997 Revised version accepted for publication

24 November 1997

\begin{abstract}
A set of neurofibromatosis type 1 (NF1) patients was screened for large NF1 gene deletions by comparing patient and parent genotypes at 10 intragenic polymorphic loci. Of 67 patient/parent sets (47 new mutation patients and 20 familial cases), five $(7.5 \%)$ showed loss of heterozygosity (LOH), indicative of NF1 gene deletion. These five patients did not have severe NF1 manifestations, mental retardation, or dysmorphic features, in contrast to previous reports of large NF1 deletions. All five deletions were de novo and occurred on the maternal chromosome. However, two patients showed partial LOH, consistent with somatic mosaicism for the deletion, suggesting that mosaicism may be more frequent in NF1 than previously recognised (and may have bearing on clinical severity). We suggest that large NF1 deletions (1) are not always associated with unusual clinical features, (2) tend to occur more frequently on maternal alleles, and (3) are an important mechanism for constitutional and somatic mutations in NF1 patients.

$(\mathcal{F}$ Med Genet 1998;35:468-471)
\end{abstract}

Keywords: neurofibromatosis type 1; deletions; somatic mosaicism; loss of heterozygosity

Neurofibromatosis type 1 (NF1) is a common autosomal dominant condition occurring in approximately 1 in 3000 people. NF1 is characterised by café au lait spots, neurofibromas, axillary freckling, and iris Lisch nodules. Subjects with this condition are also at an increased risk of malignancy. ${ }^{1}$ The NF1 gene is large, spanning $350 \mathrm{~kb}$ of genomic DNA, and contains 59 exons. $^{2}$ The gene encodes a cytoplasmic protein called neurofibromin, believed to have a tumour suppressor role. The search for NF1 mutations has proven to be particularly challenging, owing to the large gene size, its high mutation rate, and the paucity of recurrent mutations. Over 100 mutations have been published and in only a few cases has the same mutation been identified in unrelated patients. ${ }^{3}$ The majority of published mutations are predicted to result in translation of truncated neurofibromin, and therefore presumably absence of a functional protein product. However, the protein truncation test recently developed for use in NF1 has been successful in identification of about two-thirds of mutations, ${ }^{4}$ leaving one-third of mutations undetected. Since large gene dele- tions would escape detection by the protein truncation test as well as most other mutation identification methods previously used in NF1, we sought to identify large gene deletions in NF1 using loss of heterozygosity (LOH) analysis. We genotyped 67 typical patients and their parents at 10 intragenic NF1 loci (fig 1) to look for failure to inherit one parental allele (LOH), indicative of a deletion.

\section{Patients, material, and methods}

PATIENTS

Patients met accepted NF1 diagnostic criteria. ${ }^{20}$ Forty-seven patients were new mutations; DNA was available from both parents in 35 of these patients, and from one parent in the remaining 12 cases (11 mothers, one father). Twenty affected parent-child pairs were also studied. This study was begun before any mutations had been found in this group, and patients were not excluded if a mutation was subsequently identified using other means.

\section{PCR ANALYSES}

Blood was obtained under IRB consent from patients and their parents, and DNA was extracted according to published methods. ${ }^{21}$ One patient's B cells were also transformed into a lymphoblastoid cell line with Epstein Barr virus. ${ }^{22}$ Ten markers (noted in fig 1) were genotyped for all patients; if the patient was apparently homozygous at a marker, the parents were also genotyped at that marker. When loss of a parental allele was identified, flanking markers were also studied. The markers were genotyped as described in the references, with the exception of a modified, non-radioactive approach for the $A l u$ tetranucleotide polymorphism. ${ }^{11}$ This PCR product was digested with $B f a I$, which cuts the product into a constant $268 \mathrm{bp}$ fragment and a polymorphic fragment varying in size from 127 to $139 \mathrm{bp}$. These fragments were resolved on $10 \%$ native polyacrylamide gels, stained with ethidium bromide, and visualised under UV illumination.

\section{SOUTHERN BLOT ANALYSES}

Samples in which PCR based analyses showed loss of a parental allele were used for Southern blot analyses to confirm deletions and to assist in identifying deletion endpoints. Southern blots were performed as described previously ${ }^{23}$ using PstI digested DNA from the five putative deletion patients and Hybond $\mathrm{N}$ nylon membranes (Amersham). The probes were labelled with $\alpha^{32} \mathrm{P}$-dCTP using a random prime system (Amersham Multiprime). Probes included 


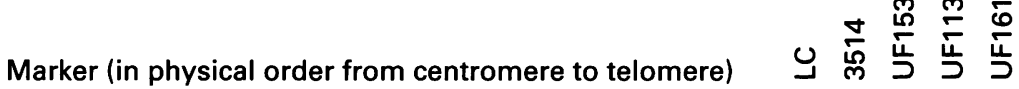

\begin{tabular}{|c|c|c|c|c|c|}
\hline & HHH202 (D17S33) [5] & 0 & 0 & 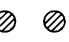 & \\
\hline & VAW212 (D17S117) [6] & $\oslash$ & $\oslash$ & 0 & 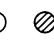 \\
\hline & UT172 (D17S635) [7] & $\oslash$ & - & $\theta$ & \\
\hline & Exon 5 RFLP* [8] & $\oslash$ & $\oslash$ & $\oslash$ & \\
\hline & Exon 13 RFLP [9] & $\oslash$ & $\oslash$ & $\oslash$ & \\
\hline & $($ GATN)n (Intron 26)* [10] & 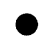 & $\oslash$ & 0 & \\
\hline$\varepsilon_{\infty}$ & Alu (AAAT)n (Intron 27b)* [11] & ○ & - & 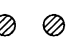 & \\
\hline 空 & EVI2B RFLP (Intron 27b)* [12] & $\oslash$ & $\oslash$ & $\oslash$ & \\
\hline 히 & IVS27TG24.8 (Intron 27b)* [13] & $\oslash$ & $\oslash$ & $\oslash$ & \\
\hline 늘 & EVI2A RFLP (Intron 27b)* [12] & $\oslash$ & $\oslash$ & $\oslash$ & $\partial$ \\
\hline & IVS27AC28.4 (Intron 27b)* [13] & $\oslash$ & - & 0 & \\
\hline & IVS38TG53.0 (Intron 38)* [14] & 0 & $\oslash$ & $\oslash$ & $\Rightarrow$ \\
\hline & Intron 39 RFLP* [15] & $\oslash$ & $\oslash$ & $\oslash$ & $\partial$ \\
\hline & Intron 41 RFLP* [16] & $\theta$ & $\theta$ & $\theta$ & $\partial$ \\
\hline & p11-1F10 (D17S135) [17] & $\oslash$ & $\oslash$ & $\oslash$ & $\theta$ \\
\hline & EW206 (D17S57) [18] & $\bigcirc$ & 0 & 0 & D \\
\hline & EW207 (D17S73) [18] & 0 & 0 & 0 & \\
\hline & Mfd 15 (D17S250) [19] & 0 & 00 & 00 & \\
\hline
\end{tabular}

Figure 1 Results of LOH studies at NF1 and flanking polymorphisms in five deletion patients, with markers studied in all 67 patients marked with an asterisk. Black circles denote deleted loci, hatched circles denote uninformative loci, and white circles denote non-deleted loci. Reference numbers in square brackets. Estimated locations of flanking markers relative to NF1 are as follows: $H H H 202,0.6 \mathrm{cM}$ upstream; VAW212, $0.1 \mathrm{cM}$ upstream; UT172, 1.5 Mb upstream; p11-1F10, 70 kb downstream; EW206/EW207, 4.8 $c M$ downstream; $M$ fd 15, 7-12 cM downstream. It was not possible to genotype the mother of 3514 for VAW212 and 1 F10.

\section{p11-1F10} (D17S135), ${ }^{17}$

VAW 212 (D17S117), ${ }^{6}$ and 17L1A. ${ }^{24}$ While VAW212 and $\mathrm{p} 11-1 \mathrm{~F} 10$ detect polymorphisms, allowing LOH analysis to be performed, interpretation of the probe $17 \mathrm{~L} 1 \mathrm{~A}$ required comparison to a control marker, a $0.6 \mathrm{~kb} \mathrm{NotI} / E c o \mathrm{RI}$ fragment of SNRPN from chromosome $15,{ }^{25}$ to normalise lane loading. Densitometry, used to analyse 17L1A (5' end of NF1) and the chromosome 15 control, used the SigmaGel (Jandel Scientific) program.

\section{Results}

NF1 deletions were identified in five new mutation patients (LC, 3514, UF153, UF113, and UF161). Clinical features in these patients are summarised in table 1 . Results of $\mathrm{LOH}$ at $\mathrm{NF} 1$ and flanking polymorphic markers are shown in fig 1 . Two patients had partial LOH (UF161 and UF113), indicative of somatic mosaicism for the NF1 deletion. Patient UF161 was previously reported as the first proven case of somatic mosaicism in $\mathrm{NF}^{26}$; the majority of her leucocytes have the deletion. In contrast, the lymphocytes of UF113 showed the deletion in a smaller percentage of cells, such that the maternal allele is always visible but reduced in intensity. This held true in DNA from both a lymphoblastoid cell line and from fresh blood leucocytes. Fig 2 shows LOH in patients with constitutional deletions and partial LOH in UF113 at two markers.

Southern blot densitometry results suggested that the deletions in these five patients included the $5^{\prime}$ end of NF1 (17L1A, a probe at the 5 ' end of intron 1 ) (fig 3 ). The visually evident decreased intensity of hybridisation at this marker was confirmed by densitometry.

\section{Discussion}

Using $\mathrm{LOH}$ analysis, we have identified five patients with NF1 deletions ( $7.5 \%$ of patients studied and $10.6 \%$ of the new mutation cases). The precise endpoints of these deletions have yet to be determined; however, the deletions appear to involve most of the NF1 gene. While UF153 was informative at only one locus, located in intron $27 \mathrm{~b}$, she was homozygous at all other NF1 markers and showed deletion by densitometry at $17 \mathrm{~L} 1 \mathrm{~A}$, located at the 5 ' end of intron 1 . Since our primary detection strategy depends on marker informativeness, this percentage should be viewed as a conservative estimate of large NF1 deletions. These deletions would not have been identified by the protein truncation test or most other PCR based mutation detection methods, and thus $\mathrm{LOH}$ analysis is an important complementary mutation detection technique.

Previous studies testing for large NF1 gene deletions have used methods such as fluorescence in situ hybridisation (FISH), ${ }^{27-30}$ Southern based and somatic cell hybrid analyses, ${ }^{31}$ pulsed field gel electrophoresis (PFGE), ${ }^{32}{ }^{33}$ and $\mathrm{LOH}$ at a smaller number of intragenic markers ${ }^{34}{ }^{40} \mathrm{LOH}$ analysis has the advantage of being able to detect deletions encompassing even a single marker ${ }^{41}$ while using relatively small amounts of DNA. The disadvantages of this technique include its dependence on the informativeness of intragenic markers and the need for parental DNA. However, the high degree of heterozygosity for the microsatellite markers provides the opportunity to screen patients for these markers before obtaining parental DNA or performing dosage based analyses in patients with apparent homozygosity at all or most markers studied.

Other recent studies have found similar proportions $(4-7 \%)$ of NF1 patients with large NF1 gene deletions. ${ }^{37-40}$ However, the patients with large NF1 deletions in our study do not appear to be more severely affected than

Table 1 Summary of clinical features in patients with NF1 deletions

\begin{tabular}{|c|c|c|c|c|c|}
\hline & $L C$ & 3514 & UF153 & UF113 & $U F 161$ \\
\hline Age at examination $(y)$ & 20 & 11 & 9 & 10 & 31 \\
\hline Café au lait spots & Multiple & Multiple & Multiple & Multiple & Multiple \\
\hline Cutaneous neurofibromas & Multiple & Several & None & Two & Multiple \\
\hline Axillary freckling & Yes & Yes & Yes & Yes & Yes \\
\hline Macrocephaly & Unknown & No & Yes & No & Yes \\
\hline $\begin{array}{l}\text { Mental retardation/learning } \\
\text { disabilities }\end{array}$ & $\begin{array}{l}\text { Normal to low } \\
\text { normal IQ }\end{array}$ & $\begin{array}{l}\text { "Learning } \\
\text { disabilities" }\end{array}$ & Normal & Normal & Normal \\
\hline Other features & Scoliosis & $\begin{array}{l}\text { Right fibular } \\
\text { pseudarthrosis }\end{array}$ & $\begin{array}{l}\text { Mild scoliosis, hypothalamic glioma } \\
\text { causing precocious puberty }\end{array}$ & $\begin{array}{l}\text { Mild hemihypertrophy, bilateral } \\
\text { sensorineural hearing loss }\end{array}$ & - \\
\hline
\end{tabular}




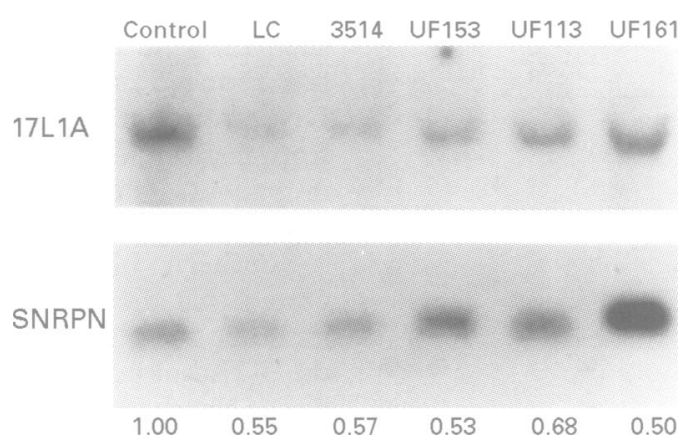

Figure 3 Southern blot results for control and deletion patients using 17L1A (at 5' end of the gene) and

chromosome 15 control probe (SNRPN), showing deletion extending through $17 \mathrm{~L} 1 \mathrm{~A}$ in all cases. Results of

densitometric analysis are listed below each lane; the ratio in the control lane was assigned as 1.00 , with ratios in the other lanes being compared to this control. The low level contribution of non-deleted cells in UF161 was indistinguishable from a non-mosaic deletion patient using this analysis.

patients with frameshift or point mutations, nor do they have other features (dysmorphism or mental retardation) suggestive of a contiguous gene syndrome, ${ }^{42}$ as has been seen in other NF1 patients with large deletions involving flanking DNA. ${ }^{27} 29313943$ Since the deletion endpoints have not been delineated, it is unclear if this difference is the result of a smaller deletion size or other modifying genes. In all cases, though, it is clear that most of the NF1 gene is lost. Previous studies suggest that a large proportion of cases with severe NF1 manifestations, dysmorphic features, and mental retardation/learning disabilities have large NF1 deletions. ${ }^{27}{ }^{31}$ Our patients were not preselected for severity of NF1 features, but rather were chosen based on availability of parental DNA, and, in retrospect, all of the patients have NF1 features within the typical range of expression. While large gene deletions may be more frequent among dysmorphic and severe NF1 patients, this mutation mechanism also appears to be important among typical NF1 cases.

All five large gene deletions described here occurred on the maternally derived chromosome. Given the small numbers, this finding could be the result of chance, especially since samples from parent-child pairs more often included a mother than a father. However, other reports also suggest that large deletions
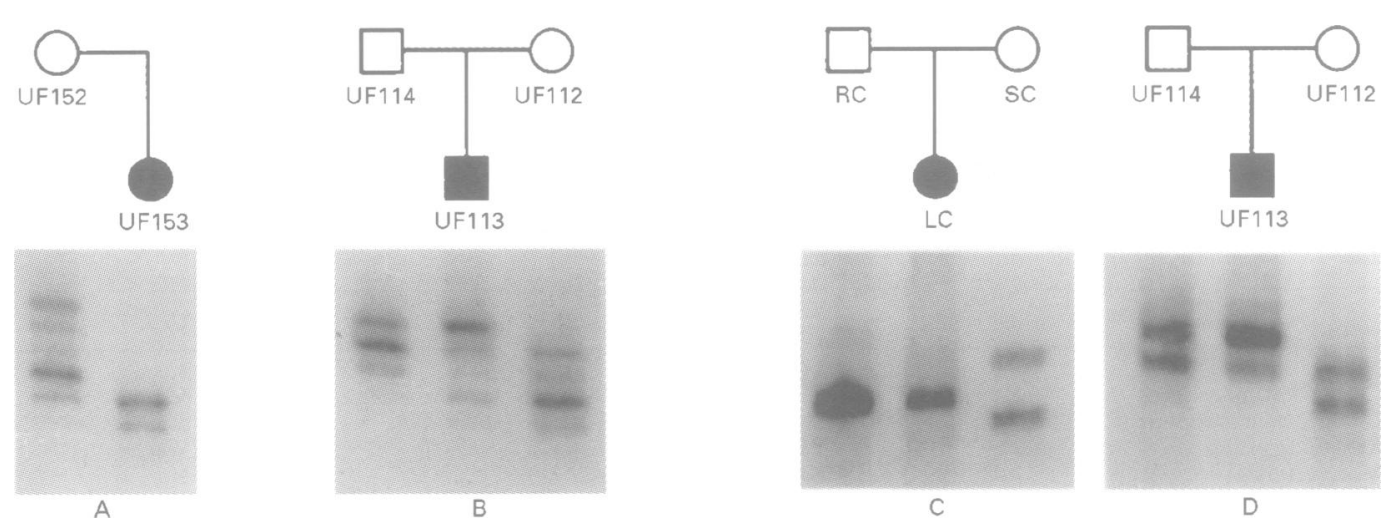

Figure 2 Results of LOH studies at microsatellites IVS27AC28.4 in intron $27 b(A, B)$ and (GATN)n in intron $26(C$, $D)$. $(A)$ and $(C)$ show complete $L O H$, indicative of deletion of the maternally derived allele. (B) and (D) show partial $L O H$, indicative of somatic mosaicism in UF113. recent study, inheritance of intragenic and flanking markers was examined in a series of new mutation NF1 cases; two of 11 (18\%) non-deletion cases were shown to be of maternal origin, while 16 of 21 (76\%) deletion cases were maternally derived. ${ }^{37}$ This predominance of maternal derivation of NF1 gene deletions is particularly significant when compared to previous studies which suggested that about $90 \%$ of new NF1 mutations are paternal in origin. ${ }^{44}{ }^{45}$ These results suggest that in NF1, as in other genetic conditions (for example, haemophilia and Duchenne muscular dystrophy), the parental origin of new mutations may vary with mutation type, with deletions occurring more frequently in oogenesis. ${ }^{46-49}$ The significance of the maternal origin of germline and somatic mutations is unknown.

Two of five patients with NF1 deletions were identified as having somatic mosaicism. In one patient (UF161), the majority of her leucocytes showed the deletion (her results were indistinguishable from other constitutional deletion patients based on the Southern densitometry, and represented more than $95 \%$ of cells, based on subcloning of informative PCR products ${ }^{26}$ ). In the other patient (UF113), a smaller proportion of leucocytes appear to show the deletion, as evidenced by Southern results. However, estimation of degree of mosaicism in leucocytes is not of particular significance since different tissues have been shown to have varying degrees of mosaicism. ${ }^{2630}$

The finding of mosaicism in two of five patients with NF1 deletions suggests that this phenomenon may be more frequent in NF1 than previously recognised. Any number of the remaining 62 patients could be mosaic as well, for mutations not detected by this method. In addition to these two cases, one of which we previously reported ${ }^{26}$ there have been two other reports of somatic mosaicism for large NF1 deletions. ${ }^{30} 38$ The finding that somatic mosaicism is not a rare event in NF1 is of clinical significance because: (1) an increased recurrence risk can be excluded in the unaffected parents of these patients; (2) the risk of transmission of NF1 from a parent with somatic mosaicism is unknown, but is probably less than $50 \%$ (this risk could be approximated in a study of sperm from mosaic males); (3)

are primarily maternally derived. ${ }^{35} 373840$ In a 
mosaicism may explain why some patients have limited NF1 features without meeting diagnostic criteria; and (4) the cellular distribution of the deletion may be such that blood (virtually the only tissue tested in diagnostic laboratories) may not show the mutation (especially with some techniques), which could lead to underdiagnosis. Finally, the only NF1 mosaic mutations detected so far have been large deletions; it is possible that mosaicism for other more subtle mutations occurs as well in NF1 patients, and thus this phenomenon must be routinely considered by geneticists.

We would like to thank the patients and their families for their participation in this study. This work was supported by grants to MRW from the American Cancer Society (Florida Division, F93UF-3), Hayward Foundation, Children's Miracle Network, and NIH/R29NS31550, and support from the R C Philips Unit, State of Florida. SAR is supported by NIH training grant F32CA72199, and SDC was supported by NIH training grant T32CA09126. We thank Dr D J Driscoll for his contribution of the SNRPN probe.

1 Huson SM, Compston DAS, Clark P, Harper PS. A genetic study of von Recklinghausen neurofibromatosis in southeast Wales. I. Prevalence, fitness, mutation rate, and effect of parental transmission on severity. $\mathcal{f}$ Med Genet 1989;26:704-11.

$2 \mathrm{Li} \mathrm{Y,} \mathrm{O'Connell} \mathrm{P,} \mathrm{Breidenbach} \mathrm{HH,} \mathrm{et} \mathrm{al.} \mathrm{Genomic} \mathrm{organi-}$ zation of the neurofibromatosis 1 gene (NF1). Genomics zation of the

3 Shen MH, Harper PS, Upadhyaya M. Molecular genetics of neurofibromatosis type 1 (NF1). $\mathcal{F}$ Med Genet 1996;33:217.

4 Heim RA, Kam-Morgan LN, Binnie CG, et al. Distribution of 13 truncating mutations in the neurofibromatosis 1 gene. Hum Mol Genet 1995;4:975-81.

5 Ainsworth PJ, Rodenhiser DI. Rapid nonradioactive detection by PCR of pHHH202/RsaI RFLP linked to neurofibromatosis type 1. Am $\mathcal{F}$ Hum Genet 1991;49:1098-9.

6 Fain PR, Goldgar DE, Wallace MR, et al. Refined physical and genetic mapping of the NF1 region on chromosome 17. Am $\mathcal{F}$ Hum Genet 1989;45:721-8.

7 Shannon KM, O'Connell P, Martin GA, et al. Loss of the normal $N F 1$ allele from the bone marrow of children with type 1 neurofibromatosis and malignant myeloid disorders. N Engl $\mathcal{F}$ Med 1994;330:597-601.

8 Hoffmeyer S, Assum G. An RsaI polymorphism in the transcribed region of the neurofibromatosis (NFI)-gene. Hum Scribed region of the

9 Régnier V, Danglot G, Nguyen VC, Bernheim A. A Tsp509I variant in exon 13 of the neurofibromatosis type 1 (NF1) gene allows the identification of both alleles at the mRNA level. Hum Genet 1995;96:131-2.

10 Andersen LB, Tarlé SA, Marchuk DA, Legius E, Collins FS. A compound nucleotide repeat in the neurofibromatosis (NF1) gene. Hum Mol Genet 1993;2:1083.

$11 \mathrm{Xu} \mathrm{GF}$, Nelson L, O'Connell P, White R. An Alu polymorphism intragenic to the neurofibromatosis type 1 gene (NF1). Nucleic Acids Res 1991;19:3764.

12 Rasmussen SA, Ho VT, Colman SD, Abernathy CR, Wallace MR. A multiplex-PCR test for $E V I 2 A$ and $E V I 2 B$ polymorphisms with the human NF1 gene. Mammalian Genome 1996; 7:233-4.

13 Lázaro C, Gaona A, Estivill X. Two CA/GT repeat polymorphisms in intron 27 of the neurofibromatosis type polymorphisms in intron 27 of the neurofib

14 Lázaro C, Gaona A, Xu G, Weiss R, Estivill X. A highly informative CA/GT repeat polymorphism in intron 38 of the human neurofibromatosis type 1 (NF1) gene. Hum Genet 1993;92:429-30.

15 Abernathy C, Colman SD, Wallace MR. A PCR-based test for a polymorphism within the human NF1 gene. Clin Genet 1994;45:313.

16 Shen $M H$, Upadhyaya $M$. Two single base polymorphisms in introns 41 and 16 of the NF1 gene. Am F Med Genet 1995;60:147-9.

17 Jorde LB, Watkins WS, Viskochil D, O'Connell P, Ward $\mathrm{K}$ Linkage disequilibrium in the neurofibromatosis 1 (NF1) for gene mapping. Am 7 Hum Genet 1993;53:1038-50.

18 Rodenhiser DI, Coulter-Mackie MB, Singh SM. Evidence of DNA methylation in the neurofibromatosis type 1 (NFI) of

19 Weber JL, Kwitek AE, May PE, Wallace MR, Collins FS, Ledbetter DH. Dinucleotide repeat polymorphisms at the D17S250 and D17S261 loci. Nucleic Acids Res 1990;18: 4640 .

20 Gutmann DH, Ayslworth A, Carey JC, et al. The diagnostic evaluation and multidisciplinary management of neurofibromatosis 1 and neurofibromatosis 2. FAMA 1997;278: 51-7.

21 Madisen L, Hoar DI, Holroyd CD, Crisp M, Hodes ME DNA banking: the effects of storage of blood and isolated
DNA on the integrity of DNA. Am $f$ Med Genet 1987;27:379-90.

22 Neitzel H. A routine method for the establishment of permanent growing lymphoblastoid cell lines. Hum Genet 1986;73:320-6.

23 Wallace MR, Marchuk DA, Andersen LB, et al. Type 1 neurofibromatosis gene: identification of a large transcript disrupted in three NF1 patients. Science 1990;249:181-6.

24 Wallace MR, Fountain JW, Brereton AM, Collins FS. Direct construction of a chromosome-specific NotI linking library from flow-sorted chromosomes. Nucleic Acids Res 1989;17: 1665-77.

25 Glenn CC, Saitoh S, Jong MTC, et al. Gene structure, DNA methylation, and imprinted expression of the human SNRPN gene. Am F Hum Genet 1996;58:335-46.

26 Colman SD, Rasmussen SA, Ho VT, Abernathy CR, Wallace MR. Somatic mosaicism in a patient with neurofibromatosis type 1. Am $\mathcal{F}$ Hum Genet 1996;58:484-90.

27 Wu BL, Austin MA, Schneider GH, Boles RG, Korf BR Deletion of the entire NF1 gene detected by FISH: four deletion patients associated with severe manifestations. $\mathrm{Am}$ f Med Genet 1995;59:528-35.

28 Leppig KA, Viskochil D, Neil S, et al. The detection of contiguous gene deletions at the neurofibromatosis 1 locus with fluorescence in situ hybridization. Cytogenet Cell Genet 1996;72:95-8.

29 Wu BL, Schneider GH, Korf BR. Deletion of the entire NF1 gene causing distinct manifestations in a family. $\mathrm{Am} \mathcal{F} \mathrm{Med}$ Genet 1997;69:98-101.

30 Wu BL, Boles RG, Yaari H, Weremowicz S, Schneider GH, Korf BR. Somatic mosaicism for deletion of the entire $N F 1$ gene identified by FISH. Hum Genet 1997;99:209-13.

31 Kayes LM, Burke W, Riccardi VM, et al. Deletions spanning the neurofibromatosis 1 gene: identification and phenotype of five patients. Am $\mathcal{f}$ Hum Genet 1994;54:424-36.

32 Upadhyaya $\mathrm{M}$, Cheryson A, Broadhead W, et al. A $90 \mathrm{~kb}$ DNA deletion associated with neurofibromatosis type $1 . \mathcal{F}$ Med Genet 1990;27:738-41.

33 Viskochil D, Buchberg AM, Xu G, et al. Deletions and a translocation interrupt a cloned gene at the neurofibromatosis type 1 locus. Cell 1990;62:187-92.

34 Lázaro C, Gaona A, Ravella A, et al. Novel alleles, hemizygosity and deletions at an Alu-repeat within the neurofibromatosis type 1 (NFI) gene. Hum Mol Genet 1993;2: 725-30.

35 Upadhyaya M, Maynard J, Osborn M, et al. Characterisation of germline mutations in the neurofibromatosis type 1 (NF1) gene. F Med Genet 1995;32:706-10.

36 Grifa A, Piemontese MR, Melchionda S, et al. Screening of neurofibromatosis type 1 gene: identification of a large deletion and of an intronic variant. Clin Genet 1995;47: 281-4.

37 Lázaro C, Gaona A, Ainsworth P, et al. Sex differences in mutational rate and mutational mechanism in the NFI gene in neurofibromatosis type 1 patients. Hum Gener 1996;98:696-9.

38 Ainsworth PJ, Chakraborty PK, Weksberg R. Example of somatic mosaicism in a series of de novo neurofibromatosis type 1 cases due to a maternally derived deletion. Hum Mutat 1997;9:452-7.

39 Cnossen $M H$, van der Est $M N$, Breuning $M H$, et al. Deletions spanning the neurofibromatosis type 1 gene: Deletions spanning the neurofibromatosis type 1 gene:
implications for genotype-phenotype correlations in neuimplications for genotype-phenotype correlations

40 Valero MC, Pascual-Castroviejo I, Velasco E, Moreno F, Hernández-Chico $C$. Identification of de novo deletions at the NF1 gene: no preferential paternal origin and phenotypic analysis of patients. Hum Genet 1997;99:720-6.

41 Lázaro C, Gaona A, Lynch M, Kruyer H, Ravella A, Estivill $\mathrm{X}$. Molecular characterization of the breakpoints of a 12-kb deletion in the NF1 gene in a family showing germ-line mosaicism. Am f Hum Genet 1995;57:1044-9.

42 Schmickel $\mathrm{RD}$. Contiguous gene syndromes: a component of recognizable syndromes. $\mathcal{F}$ Pediatr 1986;109:231-41.

43 Kayes LM, Riccardi VM, Burke W, Bennett RL, Stephens $\mathrm{K}$. Large de novo DNA deletion in a patient with sporadic neurofibromatosis 1 , mental retardation, and dysmorphism. F Med Genet 1992;29:686-90.

44 Jadayel D, Fain P, Upadhyaya $M$, et al. Paternal origin of new mutations in von Recklinghausen neurofibromatosis. Nature 1990;343:558-9.

45 Stephens K, Kayes L, Riccardi VM, Rising M, Sybert VP, Pagon RA. Preferential mutation of the neurofibromatosis type 1 gene in paternally derived chromosomes. Hum Genet 1992;88:279-82.

46 Brocker-Vriends AHJT, Rosendaal FR, Van Houwelingen $\mathrm{JC}$, et al. Sex ratio of the mutation frequencies in haemophilia A: coagulation assays and RFLP analysis. $\mathcal{f}$ Med Genet 1991;28:672-80.

47 van Essen $\mathrm{AJ}$, Abbs S, Baiget $\mathbf{M}$, et al. Parental origin and germline mosaicism of deletions and duplications of the dystrophin gene: a European study. Hum Genet 1992;88: 249-57.

48 Ketterling RP, Vielhaber E, Bottema CDK, et al. Germ-line origins of mutations in families with hemophilia B: the sex ratio varies with the type of mutation. Am $\mathcal{F}$ Hum Genet 1993;52:152-66.

49 Grimm T, Meng G, Liechti-Gallati S, Bettecken T, Müller $C R$, Müller $B$. On the origin of deletions and point mutations in Duchenne muscular dystrophy: most deletions arise in oogenesis and most point mutations result from events in spermatogenesis. $\mathcal{F}$ Med Genet 1994;31:183-96. 